\title{
Receptor Tyrosine Kinase and p16/CDKN2 Expression in a Case of Tripe Palms Associated with Non-Small-Cell Lung Cancer
}

\author{
G. Krähn ${ }^{a, b}$ K.M. Greulicha,b G. Bezold ${ }^{a}$ C. Dieterle ${ }^{c}$ H. Wolff ${ }^{b}$ R.U. Peter ${ }^{a}$ \\ ${ }^{a}$ Department of Dermatology, University of UIm, and Departments of ${ }^{b}$ Dermatology and ${ }^{c}$ Internal Medicine, \\ Ludwig Maximilian University, Munich, Germany
}

\section{Key Words}

Tripe palms - Paraneoplastic disease - Epidermal growth factor receptor - HER2 - HER3 - SRC . p16/CDKN2 $\cdot$ c-myc oncogene $\cdot$ Reverse-transcription polymerase chain reaction. Non-small-cell lung cancer

\begin{abstract}
Background: Tripe palms is a descriptive term for a cutaneous paraneoplastic keratoderma. Tripe palms are frequently associated with gastric and pulmonary carcinoma. The pathogenetic mechanism remains unknown. Objective: To determine the influence of receptor tyrosine kinases, which are both expressed in pulmonary carcinomas and in human skin, we performed expression studies on epidermal growth factor receptor (EGFR), HER2, HER3 in a skin sample of tripe palms obtained from a patient with non-small-cell lung cancer with lymph node involvement. Two months after diagnosis, the patient had developed palmoplantar 'tripe palms'. Additionally, the expression of SRC, c-myc and p16/ CDKN2 were studied. Method: Conventional reversetranscription polymerase chain reaction was performed on a tissue sample of tripe palms. Results: Weak expression of HER2 and of p16/CDKN2 was found. EGFR, HER3, c-myc and SRC were not expressed. Conclusion: Receptor tyrosine kinases of subclass I, the tyrosine kinase SRC and the oncogene c-myc play no major role in the pathogenesis of this case of tripe palms.
\end{abstract}

(c) 1999 S. Karger AG, Basel

1018-8665/99/1994-0290\$17.50/0

Fax +4161306 1234

E-Mail karger@karger.ch

www.karger.com
Accessible online at:

www.karger.com/journals/drm
Tripe palms is a descriptive term for a rare cutaneous paraneoplastic keratoderma referring to the rugose surface of bovine foregut, which when prepared as food is known as tripe. The term was first introduced in 1977 by J. Clark [1]. The disease is characterized by thickening of the epidermis leading to a velvety texture and the accentuation of the normal dermatoglyphic ridges and sulci of palms and soles. Tripe palms are most frequently associated with gastric cancer $(27 \%)$ and, as in our case, pulmonary carcinoma $(22 \%)[2,3]$. Approximately 80 cases of tripe palms [1-8] have been described in the literature, not only in association with gastric and pulmonary carcinoma but also with e.g. melanomas, lymphomas, carcinomas of the entire gastrointestinal tract and urogenital tract, mammary carcinomas and carcinomas of the central nervous system. The isolated occurrence of tripe palms is more frequently found in pulmonary carcinoma, whereas $55 \%$ of patients with the combination of tripe palms and acanthosis nigricans suffer from gastric carcinoma [9]. In contrast to our patient, tripe palms in most cases develop prior to the diagnosis of the malignant disease [10]. Tripe palms are known to be a paraneoplastic disease, the pathogenesis, however, remains obscure. It has been speculated that the human growth hormone or related proteins, epidermal growth factor (EGF) or tissue growth factor $\alpha$ (TGF- $\alpha$ ) may cause tripe palms [1, 11-13]. In order to elucidate the pathogenetic role of receptor tyrosine kinases (RTKs), which represent binding sites for EGF and TGF- $\alpha$, we studied the expression of EGF receptor (EGFR), HER2, HER3 as well as SRC, a tyrosine kinase activated by RTKs in the signal transduction process. The oncogene

Dr. Gertraud Krähn

Department of Dermatology, University of Ulm

Oberer Eselsberg 40

D-89071 Ulm (Germany)

Tel. +49731502 4883, Fax +497315023772 
Fig. 1. Tripe palms, palmar aspect.

Fig. 2. Accentuation of the normal dermatoglyphic ridges and sulci.
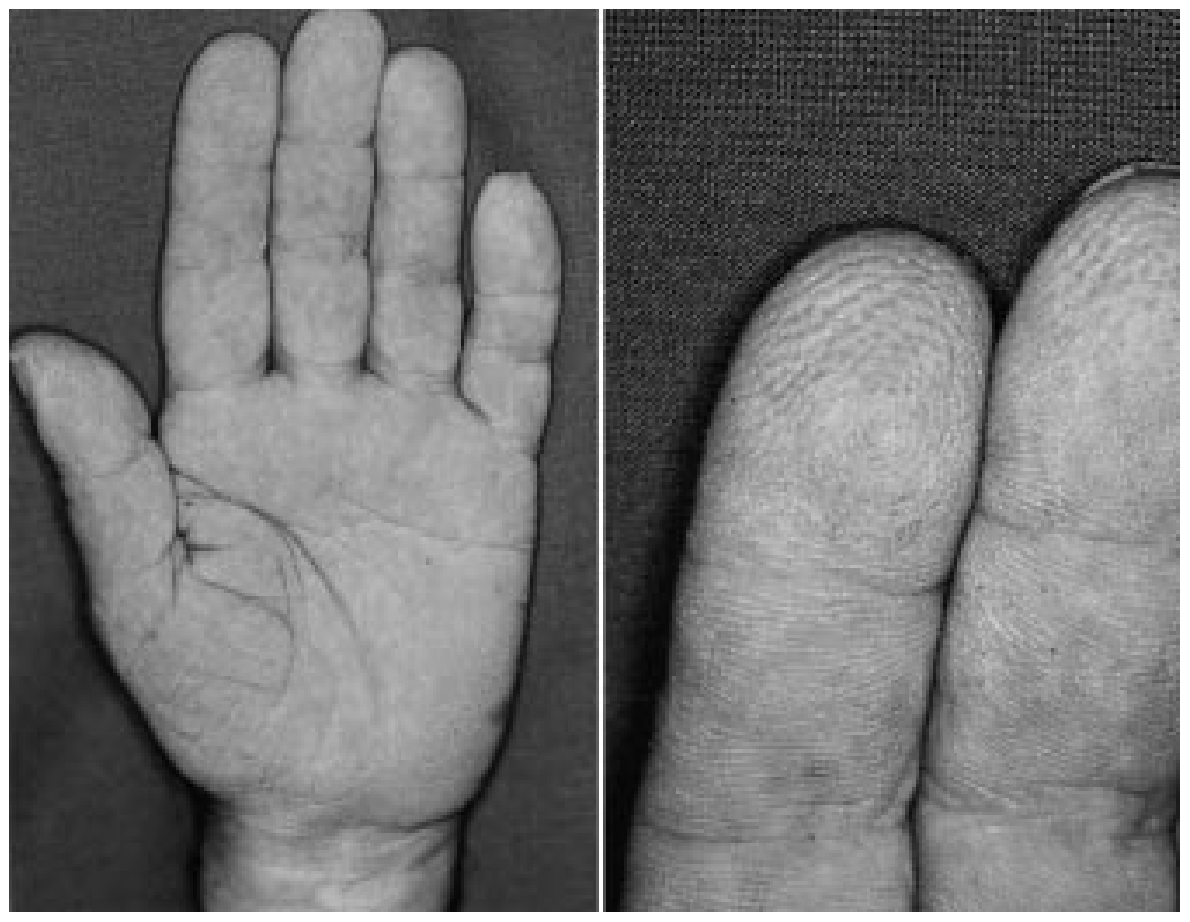

1 c-myc involved in the regulation of apoptosis as well as the expression of $\mathrm{p} 16 / \mathrm{CDKN} 2$, a tumour suppressor gene, were investigated.

\section{Patient and Methods}

Case Report

A 67-year-old Caucasian presented with chronic obstructive pulmonary disease, due to nicotine abuse and a mediastinal tumour, diagnosed as a non-small-cell lung cancer (NSCLC) with infiltration of the ganglion cervicale superius as well as cervical and mediastinal lymph nodes. Two months after diagnosis the patient developed hyperkeratotic, light yellow, velvety, non-pruritic skin changes starting on the palms followed by similar less severe skin alterations on the soles. No surgical therapy on the primary tumour or the lymph nodes was performed. Both chemotherapy (carboplatin and paclitaxel) and radiation therapy were performed, leading to a reduction of tumour size of $25 \%$ and a $50 \%$ reduction of lymph node involvement. Despite this partial remission the hyperkeratotic skin alterations remained unchanged, arguing for a continuing stimulus which - in this case - was independent of tumour size. Routine laboratory findings and human growth hormone were within the normal range. There were no endocrinological disorders such as acromegaly, Cushing's syndrome or diabetes mellitus.

On the palms and, to a lesser degree, the soles, a yellowish, velvety hyperkeratosis with accentuation of the dermatoglyphic lines with isolated hyperkeratotic papules and 'pits' was seen. Clubbing of the distal fingers, symmetric onychodystrophy and palmar hyperhydrosis were diagnosed (fig. 1,2). There were no signs of acanthosis nigricans on the trunk.

Gene Expression in Paraneoplastic Tripe

Palms
Dermatopathology revealed regular acanthosis and psoriasiform papillomatosis with orthohyperkeratosis. PAS staining was negative.

Considering the poor prognosis of lung cancer (fig. 3), we did not administer etretinate $[14,15]$. There was considerable improvement using a topical application of salicylic acid and urea-containing ointments.

Reverse-Transcription Polymerase Chain Reaction Analysis of EGFR, HER2, HER3, C-myc, SRC and p16/CDKN2

To elucidate the role of RTKs as well as SRC, c-myc and p16/CDKN2 in this case of tripe palms, we performed conventional reverse-transcription polymerase chain reaction (RTPCR) on a punch biopsy from the left palm (fig. 4).

\section{Material}

An $\mathrm{N}_{2}$-frozen tissue specimen taken from the left palm of this male Caucasian suffering from tripe palms was studied. Since no surgery was performed on the NSCLC, an expression study on the underlying tumour tissue was impossible.

\section{Methods}

The tissue sample was shock frozen in liquid nitrogen immediately after excision. The tissue was minced, total mRNAs were isolated from homogenates using the RNA-Clean ${ }^{\mathrm{TM}}$ System (Angewandte Gentechnologie Systeme GmbH, Germany). Using oligo (dt) primers, the extracted mRNA was transcribed with the Reverse Transcriptase System (Promega) to cDNA. The cDNAs were then phenol/chloroform extracted, precipitated by ethanol extraction and redissolved in $\mathrm{ddH}_{2} \mathrm{O}$. The cDNA concentration was measured by absorbance at $260 \mathrm{~nm}$. In subsequent PCR reactions ( $25 \mu \mathrm{l}), 100 \mathrm{ng}$ cDNA template from above was used to investigate the expression of the following genes. The 


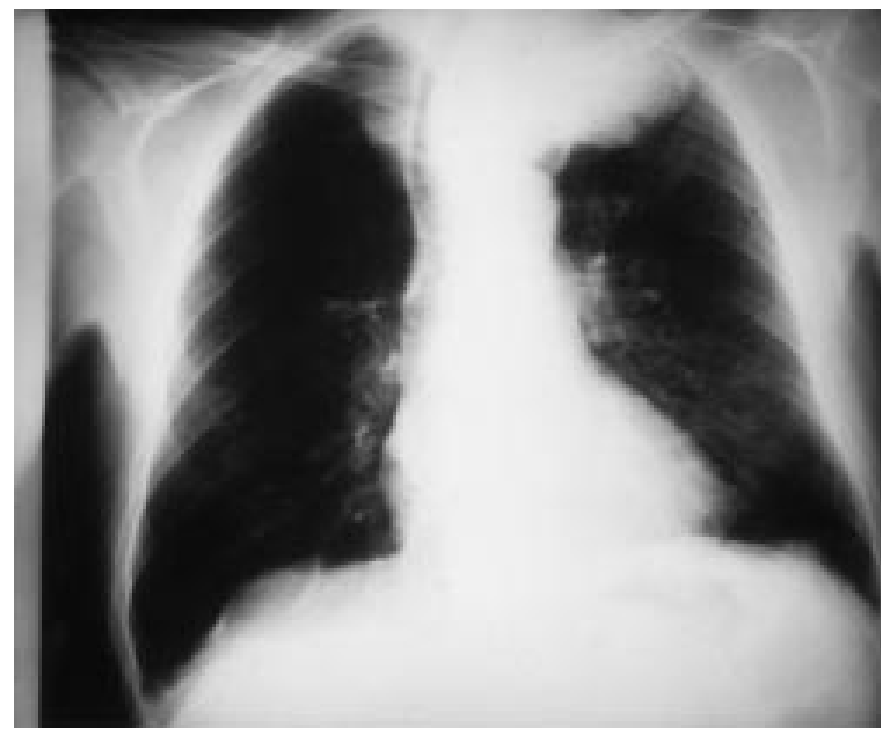

Fig. 3. Chest X-ray, NSCLC (mediastinal).

sense and antisense strand primers and cycling parameters used to detect transcripts were as follows:

EGFR: 5'-ACT AGC CAG GAA CTA CTT CC-3' and 5'-GGC CTT CTT GGA TCT TTA GT-3', predicted product size: 398 bp, cycling parameters: a first heating step $\left(94^{\circ} \mathrm{C}, 4 \mathrm{~min}\right)$, followed by $93{ }^{\circ} \mathrm{C}$ for $35 \mathrm{~s}, 60^{\circ} \mathrm{C}$ for $35 \mathrm{~s}, 72^{\circ} \mathrm{C}$ for $35 \mathrm{~s}, 35$ cycles and one final extension step $\left(68^{\circ} \mathrm{C}, 10 \mathrm{~min}\right)$; HER2: $5^{\prime}$-CGG GAG ATC CCT GAC CTG CTG GAA-3' and 5'-CTG CTG GGG TAC CAG ATA CTC CTC-3', predicted product size: $300 \mathrm{bp}$, cycling parameters: a first heating step $\left(94^{\circ} \mathrm{C}, 4 \mathrm{~min}\right)$, followed by $93^{\circ} \mathrm{C}$ for $35 \mathrm{~s}, 60^{\circ} \mathrm{C}$ for $35 \mathrm{~s}$, $72^{\circ} \mathrm{C}$ for $35 \mathrm{~s}, 35$ cycles and one final extension step $\left(68^{\circ} \mathrm{C}, 10 \mathrm{~min}\right)$; HER3: $5^{\prime}$-CUA CUA CUA CUA GAG GCT GAG CTC CAG GAG AA- $3^{\prime}$ and $5^{\prime}-$ CAU CAU CAU CAU CTG GGA CCT GGG AGA GAG AG-3', predicted prodcut size: $814 \mathrm{bp}$, cycling parameters: a first heating step $\left(94^{\circ} \mathrm{C}, 4 \mathrm{~min}\right)$, followed by $93^{\circ} \mathrm{C}$ for $35 \mathrm{~s}, 56^{\circ} \mathrm{C}$ for $35 \mathrm{~s}$, $72^{\circ} \mathrm{C}$ for $35 \mathrm{~s}, 35$ cycles and one final extension step $\left(68^{\circ} \mathrm{C}, 10 \mathrm{~min}\right)$; SRC: $5^{\prime}$-CAG ACC TGT CCT TCA AGA AA-3' and 5'-TCA GCC TGG ATG GAG TCG GA-3', predicted product size: 162 bp, cycling parameters: a first heating step $\left(94^{\circ} \mathrm{C}, 4 \mathrm{~min}\right)$, followed by $93^{\circ} \mathrm{C}$ for $35 \mathrm{~s}, 59^{\circ} \mathrm{C}$ for $35 \mathrm{~s}, 72^{\circ} \mathrm{C}$ for $35 \mathrm{~s}, 35$ cycles and one final extension step $\left(68^{\circ} \mathrm{C}, 10 \mathrm{~min}\right)$; c-myc: $5^{\prime}$-CCA GCA GCG ACT CTG AGG-3' and 5'-CCA AGA CGT TGT GTG TTC-3', predicted product size: 345 bp, cycling parameters: a first heating step $\left(94^{\circ} \mathrm{C}, 4 \mathrm{~min}\right)$, followed by $93^{\circ} \mathrm{C}$ for $35 \mathrm{~s}, 60^{\circ} \mathrm{C}$ for $35 \mathrm{~s}, 72^{\circ} \mathrm{C}$ for $35 \mathrm{~s}, 35$ cycles and one final extension step $\left(68^{\circ} \mathrm{C}, 10 \mathrm{~min}\right)$; $\mathrm{p} 16 / \mathrm{CDKN} 2: 5^{\prime}$-ATC CTG ACT GCT GTC ATG GC-3' and 5'-ACT CTT GGA AGT CCA CCT CG-3', predicted product size: for cDNA $238 \mathrm{bp}$ and genomic CNA $959 \mathrm{bp}$, cycling parameters: a first heating step $\left(94^{\circ} \mathrm{C}, 4 \mathrm{~min}\right)$, followed by $93^{\circ} \mathrm{C}$ for $35 \mathrm{~s}, 60^{\circ} \mathrm{C}$ for $35 \mathrm{~s}, 72^{\circ} \mathrm{C}$ for $35 \mathrm{~s}, 35$ cycles and one final extension step $\left(68^{\circ} \mathrm{C}, 10 \mathrm{~min}\right)$.

The PCR products had been sequenced.

The PCR mixtures contained $100 \mathrm{ng}$ of template cDNA, $1.5 \mathrm{mM}$ $\mathrm{MgCl}_{2}, 1 \mu \mathrm{m} / 25 \mu \mathrm{l}$ sense and antisense primer, $0.2 \mathrm{~m} M$ dNTPs (Promega) and Taq polymerase 1 unit (Boehringer, Mannheim, Germany). To circumvent false-negative results, we used primers detecting the GAPDH gene (Stratagene); sense 5'-CCA CCC ATG GCA AAT TCC

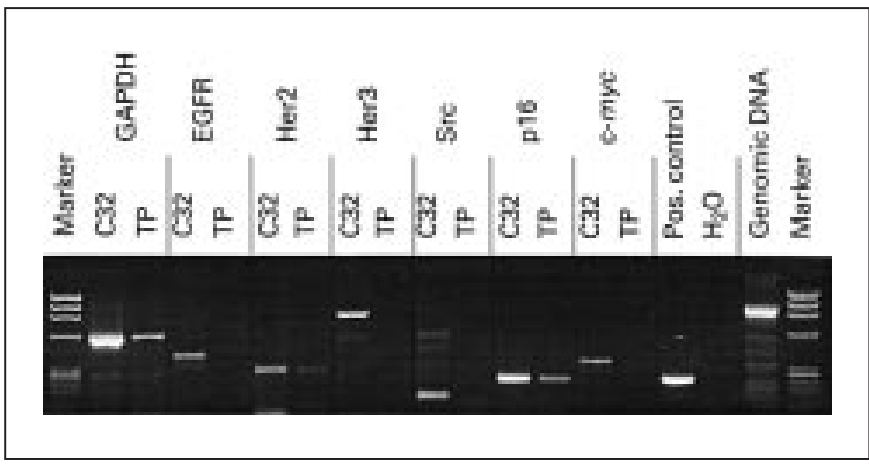

Fig. 4. $\mathrm{PCR}$ products. $\mathrm{TP}=$ Tripe palms

ATG GCA-3'; antisense 5'-TCT AGA CGG CAG GTC AGG TCC ACC-3', predicted product size: 598 bp, cycling parameters: a first heating step $\left(94^{\circ} \mathrm{C}, 4 \mathrm{~min}\right)$, followed by $93^{\circ} \mathrm{C}$ for $35 \mathrm{~s}, 60^{\circ} \mathrm{C}$ for $35 \mathrm{~s}$, $72^{\circ} \mathrm{C}$ for $35 \mathrm{~s}, 35$ cycles and one final extension step $\left(68^{\circ} \mathrm{C}, 10 \mathrm{~min}\right)$. The DNA molecular-weight standard (PhiX 174RF/HaeIII) was purchased from Boehringer Mannheim. RNA from the melanoma cell line C32, obtained from the American Type Culture Collection, was amplified as a positive control. The cell line was cultured as recommended by the American Type Culture Collection. Water instead of cDNA was applied as a negative control. In parallel genomic DNA was amplified. Following PCR, identical aliquots $(5 \mu \mathrm{l})$ were loaded on $2 \%$ agarose gels and the products were visualized by ethidium bromide staining. The optical density of bands was analysed by a computerized densitometric analysis device (Image master VDS, Pharmacia). The expression level of the genomic DNA was taken as a level for determining 'weakly positive' or 'positive' expression. Optical density in the ethidium bromide gel lower than the genomic DNA band was regarded as 'weak', similar or higher as 'positive'. Genomic contamination was ruled out by the use of $\mathrm{p} 16 / \mathrm{CDKN} 2$ primers with different product sizes for cDNA (238 bp) and genomic DNA (959 bp).

\section{Results}

The housekeeping gene GAPDH was strongly expressed. Weak expression of HER2 was detectable in the tripe palms sample, while EGFR and HER3 expression was not found. In 105 previously tested samples of normal skin, naevi and malignant melanoma, HER2 expression was detectable in all samples regardless of the dignity of the tissue (data not shown).

SRC, a tyrosine kinase involved in signal transduction downstream of RTKs [16], was not detectable either.

$\mathrm{c}-m y c$, an oncogene involved in a variety of malignant tumours [17], was not expressed. p16/CDKN2 [18, 19], a tumour suppressor gene [20], was moderately expressed. Since different product sizes for cDNA and genomic DNA are produced with these applied primers, genomic contamination could be ruled out. 


\section{Discussion}

It has been speculated that the human growth hormone or related proteins may cause tripe palms [1]. In 2 cases, high levels of immunoreactive human growth hormone were detected. The elevated level of this hormone may act as a mediator for the hypertrophic processes. Elevated levels of immunoreactive human growth hormone have also been described in patients with lung cancer. Since elevated human growth hormone as well as plasma growth-hormonereleasing hormone have been detected in serum of patients both with small-cell and non-small-cell lung carcinoma [21] without tripe palms, the development of tripe palms is not necessarily caused by the human growth hormone.

Based on the observation of an elevated EGF level in a patient with tripe palms in association with bronchial carcinoma, the role of tumour growth factors such as EGF has been discussed [11]. The overexpression of EGF in the serum of this published patient [11] could be attributable to the underlying malignant process, since elevated EGF levels were also detected in patients with lung carcinoma [22] without tripe palms.

Publications attributing a pathogenetic influence of the TGF- $\alpha$ to the development of acanthosis nigricans, a paraneoplastic skin disease with similarity to tripe palms, are based on the detection of TGF- $\alpha$ in tumour tissue but not in the skin samples $[12,13]$. A case report on a patient with systemic mastocytosis and tripe palms describes elevated serum levels of TGF- $\alpha$ and mast cells in the skin [8].

A recent concept [16] assumes that the activation of membrane-based receptor tyrosine kinases by binding of ligand such as EGF or TGF- $\alpha$ leads to the induction of signal transduction processes resulting in cell proliferation and differentiation. An elevated level of EGF or TGF- $\alpha$ should thus result in the expression of corresponding receptors such as the EGFR, expressed in a variety of malignant tumours including pulmonary carcinoma [23] and melanoma [24], or HER2, an important oncogene in mammary carcinoma $[25,26]$, or HER3 [27, 28], a closely related member of this gene family [29], expressed among others in head and neck tumours. These RTKs of subclass I are also designated erbB1-3. A further member, HER4 [30], has not yet been extensively studied in human carcinomas in vivo.

Based on these data, we investigated the role of RTKs of subclass I, which could be putative receptors for ligands such as EGF in this case of tripe palms.

Recent studies provide evidence that the family I of RTKs can associate with each other to form an array of heterodimer complexes [31-36]. Therefore, the activation of one receptor could modulate the activity of the other mem- bers of this group of RTKs when co-expressed in a cell and extend the repertoire of downstream signalling events. HER2 can - in the absence of any HER2-specific ligand be transmodulated within a heterodimer complex by associating with other HER family members. Tzahar et al. [31] came to the conclusion that HER2 might serve as the preferred heterodimerizing partner of the three other ERBb proteins.

In this case of tripe palms EGFR and HER3 are not involved in this signal transduction process. HER2 is expressed in this case of tripe palms. Isolated expression of HER 2 could theoretically - by homodimerization - be sufficient to activate signal transduction downstream of the RTKs. HER4 [30], a further RTK of subclass I which we did not test, as well as other yet unidentified RTKs might be possible candidates for further partners for heterodimerization with HER2. However, HER4 has not yet been described in adult skin or any skin cancer [37]. The lack of SRC expression hints at another signal transduction pathway activated by RTKs than the one via SRC.

HER2 expression both in vitro and in vivo has been described in NSCLC [38-42]. We found weak to strong HER2 expression in more than 100 skin samples of varying dignity (data not shown), and frequent HER2 protein expression has been described both in benign and malignant cutaneous tissue [43-45]. Despite the known HER2 expression in NSCLC, but due to the frequent HER2 expression in cutaneous tissue and its weak expression in this particular case, HER2 might not be a causative factor for NSCLCassociated paraneoplastic skin diseases, such as tripe palms.

c-myc, a transcription factor that is believed to regulate the expression of genes governing cellular growth, differentiation and apoptosis $[17,46,47]$ is - due to a lack of its expression - presumably not involved in regulatory mechanisms in this case of tripe palms.

Interestingly, p16/CDKN2, a cell cycle regulator with tumour suppressor activity [18-20], among others in malignant melanoma, was expressed in this case of tripe palms. The role of further cell cycle regulators with tumour suppressor gene potential such as p53 need to be elucidated in further studies.

Our data demonstrate that EGFR, HER3, c-myc and SRC are not involved in the pathogenesis of this case of tripe palms. Whether HER2 homodimer formation or the possible involvement of further RTKs [32] is responsible for tripe palms will have to be studied. Except for ligands such as EGF or TGF- $\alpha$, which have been detected in patients with tripe palms, yet uninvestigated RTK ligands such as heregulin [48] might furthermore play a role in the pathogenesis of tripe palms. 
Although the pathogenetic mechanisms causing tripe palms remain unclear, further studies on gene expression of growth factors and their ligands, with special respect to those involved in the underlying malignant neoplasias, may help to understand the intriguing pathways leading to paraneoplastic skin diseases.

From a clinical point of view the knowledge of tripe palms is crucial, since in $40 \%$ of patients, tripe palms are the presenting feature of a previously undiagnosed malignant neoplasia [10]. The observation of tripe palms should thus always prompt a meticulous search for an underlying malignancy.

\section{Acknowledgement}

We are grateful to C. Wallasch, A. Ullrich and P. Kind.

\section{References}

1 Breathnach SM, Wells GC: Acanthosis palmaris: Tripe palms, a distinctive pattern of palmar keratoderma frequently associated with internal malignancy. Clin Exp Dermatol 1980;5: 181-189.

2 Cohen PR, Kurzrock R: Malignancy-associated tripe palms. J Am Acad Dermatol 1992;27: 271-272.

3 Lo WL, Wong CK: Tripe palms: A significant cutaneous sign of internal malignancy. Dermatology 1992;185:151-153.

4 Clarke J: Malignant acanthosis nigricans. Clin Exp Dermatol 1977;2:167-170.

5 Hazen PG, Carney JF, Walker AE, Stewart JJ: Acanthosis nigricans presenting as hyperkeratosis of the palms and soles. J Am Acad Dermatol 1979;1:541-544.

6 Pujol RM, Puig L, Garcia-Marques JM, De Moragas JM: Acquired pachydermatoglyphy: A cutaneous sign of internal malignancy. Int $\mathrm{J}$ Dermatol 1988;27:688-689.

7 Gorisek B, Krajnc I, Rems D, Kuhelj J: Malignant acanthosis nigricans and tripe palms in a patient with endometrial adenocarcinoma. Gynecol Oncol 1997;65:539-542.

8 Chosidow O, Becherel PA, Piette JC, Arock M, Debre P, Frances C: Tripe palms associated with systemic mastocytosis: The role of transforming growth factor-alpha and efficacy of interferon-alpha. Br J Dermatol 1998;138:698703.

9 Rigel DS, Jacobs MI: Malignant acanthosis nigricans: A review. J Dermatol Surg Oncol 1980;6:923-927.

10 Cohen PR, Grossman ME, Almeida L, Kurzrock R: Tripe palms and malignancy. J Clin Oncol 1989;7:669-678.

11 Douglas F, McHeary PM, Dagg JH, MacBeth FM, Morley WN: Elevated level of epidermal growth factor in a patient with tripe palms (letter). Br J Dermatol 1994;130:686-687.

12 Koyama S, Ikeda K, Sato M, Shibahara K, Yuhara K, Fukutomi H, Fukunaga K, Kanazawa N, Yuzawa K, Fukao K: Transforming growth factor alpha (TGF $\alpha$ )-producing gastric carcinoma with acanthosis nigricans: An endocrine effect of TGF $\alpha$ in the pathegenesis of cutaneous paraneoplastic syndrome and epithelial hyperplasia of the esophagus. J Gastroenterol 1997;32:71-77.
13 Wilgenbus K, Leutner A, Kuchelhorn R, Handt $\mathrm{S}$, Mittermayer C: Further evidence that acanthosis nigricans maligna is linked to enhance secretion by the tumour of transforming growth factor $\alpha$. Arch Dermatol Res 1992;284:266270.

14 Berardesca E, Del Forno C, Vignani M: Usefulness of etretinate treatment in paraneoplastic palmoplantar hyperkeratosis. Br J Dermatol 1987;117:132-133.

15 Wishart JM: Bazex paraneoplastic acrokeratosis: A case report and response to Tigason. $\mathrm{Br} \mathrm{J}$ Dermatol 1986;115:595-599.

16 Weiss FU, Daub H, Ullrich A: Novel mechanisms of RTK signal generation. Curr Opin Genet Dev 1997;7:80-86.

17 Garte SJ: The c-myc oncogene in tumour progression. Crit Rev Oncogenesis 1993;4:435449.

18 Kamb A, Gruis NA, Weaver-Feldhaus J, Liu Q, Harshman K, Tavtigian SV, Stockert E, Day RSI, Johnson BE, Skolnick MH: A cell cycle regulator potentially involved in genesis of many tumor types. Science 1994;264:436-440.

$19 \mathrm{Kamb} \mathrm{A}$ : Role of the cell cycle regulator in hereditary and sporadic cancer. Cold Spring Harb Symp Quant Biol 1994;59:39-47.

20 Wang XQ, Gabrielli BG, Milligan A, Dickinson JL, Antalis TM, Ellem KAO: Accumulation of $\mathrm{p} 16^{\mathrm{CDKN} 2}$ in response to ultraviolet irradiation correlates with a late $S-G_{2}$ phase cell cycle delay. Cancer Res 1996;56:2510-2514.

21 Schopohl J, Losa M, Frey C, Wolfram G, Huber R, Permanetter W, von Pawel J, Müller OA, von Werder K: Plasma growth hormone (GH)-releasing hormone levels in patients with lung carcinoma. Clin Endocrinol Oxf 1991;34:463467.

22 Salomon DS, Brandt R, Ciardiello F, Normanno N: Epidermal growth factor-related peptides and their receptors in human malignancies. Crit Rev Oncol Hematol 1995;19: 183-232.

23 Pastorino U, Andreola S, Tagliabue E, Pezzella F, Incarbone M, Sozzi G, Buyse M, Menard S, Pierotti M, Rilke F: Immunocytochemical markers in stage I lung cancer: Relevance to prognosis. J Clin Oncol 1997; 15:2858-2865.

24 Krähn G, Schartl M, Peter RU: Malignant melanoma: A genetic disease. Cancer 1995;75: $1228-1237$.
25 Makar AP, Desmedt EJ, De Potter CR, Vanderheyden JS, Schatteman EA: Neu oncogene in breast cancer and its possible association with the risk of distant metastases: A retrospective study and review of literature. Acta Oncol 1990;29:931-934.

26 Slamon DJ, Clark GM, Wong SG, Levin WJ, Ullrich A, McGuire WL: Human breast cancer: Correlation of relapse and survival with amplification of the HER-2/neu oncogene. Science 1987;235:177-182.

27 Kraus MH, Issing W, Miki T, Popescu NC, Aaronson SA: Isolation and characterization of ERBB3, a third member of the ERBB/epidermal growth factor receptor family: Evidence for overexpression in a subset of human mammary tumors. Proc Natl Acad Sci USA 1989; 86:9193-9197.

28 Issing WJ, Heppt WJ, Kastenbauer ER: erbB3, a third member of the erbB/epidermal growth factor receptor gene family: Its expression in head and neck cancer cell lines. Eur Arch Otorhinolaryngol 1993;250:392-397.

29 Ullrich A, Schlessinger J: Signal transduction by receptors with tyrosine kinase activity. Cell 1990;61:203-212.

30 Plowman GD, Culouscou JM, Whitney GS, Green JM, Carlton GW, Foy L, Neubauer MG, Shoyab M: Ligand-specific activation of HER4/p180erbB4, a fourth member of the epidermal growth factor receptor family. Proc Natl Acad Sci USA 1993;90:1746-1750.

31 Tzahar E, Waterman H, Chen X, Levkowitz G, Karunagaran D, Lavi S, Ratzkin BJ, Yarden Y: A hierarchical network of interreceptor interactions determines signal transduction by $\mathrm{Neu}$ differentiation factor/neuregulin and epidermal growth factor. Mol Cell Biol 1996;16:52765287.

32 Riese DJ, Kim ED, Elenius K, Buckley S, Klagsbrun M, Plowman GD, Stern DF: The epidermal growth factor receptor couples transforming growth factor-alpha, heparin-binding epidermal growth factor-like factor, and amphiregulin to Neu, ErbB-3, and ErbB-4. J Biol Chem 1996;271:20047-20052.

33 Cohen BD, Kiener PA, Green JM, Foy L, Fell HP, Zhang K: The relationship between human epidermal growth-like factor receptor expression and cellular transformation in NIH3T3 cells. J Biol Chem 1996;271:30897-30903. 
34 Chen X, Levkowitz G, Tzahar E, Karunagaran D, Lavi S, Ben Baruch N, Leitner O, Ratzkin BJ, Bacus SS, Yarden Y: An immunological approach reveals biological differences between the two NDF/heregulin receptors, ErbB-3 and ErbB-4. J Biol Chem 1996;271:7620-7629.

35 Chan SD, Antoniucci DM, Fok KS, Alajoki ML, Harkins RN, Thompson SA, Wada HG: Heregulin activation of extracellular acidification in mammary carcinoma cells is associated with expression of HER2 and HER3. J Biol Chem 1995;270:22608-22613.

36 Earp HS, Dawson TL, Li X, Yu H: Heterodimerization and functional interaction between EGF receptor family members: A new signaling paradigm with implications for breast cancer research. Breast Cancer Res Treat 1995; 35:115-132.

37 Srinivasan A, Poulsom R, Hurst HC, Gullick WJ: Expression of the c-erb-4/HER4 protein and mRNA in normal human fetal and adult tissues and in a survey of nine solid tumour types. J Pathol 1998; 185:236-245.

38 Wolf M: Prognostische Faktoren und Therapiestrategie beim nichtkleinzelligen Bronchialkarzinom. Schweiz Rundsch Med Prax 1997;86: $1640-1646$.
39 Jacobson DR, Fishman CL, Mills NE: Molecular genetic tumor markers in the early diagnosis and screening of non-small-cell lung cancer. Ann Oncol 1995;6(suppl 3):S3-8.

40 Peoples GE, Smith RC, Linehan DC, Yoshino I, Goedegebuure PS, Eberlein TJ: Shared T cell epitopes in epithelial tumors. Cell Immunol 1995;164:279-286.

41 Yoshino I, Goedegebuure PS, Peoples GE, Parikh AS, DiMaio JM, Lyerly HK, Gazdar AF, Eberlein TJ: HER2/neu-derived peptides are shared antigens among human non-small cell lung cancer and ovarian cancer. Cancer Res 1994;54:3387-3390.

42 Kern JA, Robinson RA, Gazdar A, Torney L, Weiner DB: Mechanisms of p185HER2 expression in human non-small-cell lung cancer cell lines. Am J Respir Cell Mol Biol 1992; 6:359-363.

43 Peris K, Cerroni L, Chimenti S, Soyer HP, Höfler H: Proto-oncogene expression in dermal nevi and melanomas. Arch Dermatol Res 1991; 283:500-505.
44 Bodey B, Kaiser HE, Goldgar DE: Immunophenotypically varied cell subpopulations in primary and metastatic human melanomas: Monoclonal antibodies for diagnosis, detection of neoplastic progression and receptor directed immunotherapy. Anticancer Res 1996;16:517532.

45 Rodrigo JP, Ramos S, Lazo PS, Alvarez I, Suarez C: Amplification of ERBB oncogenes in squamous cell carcinomas of the head and neck. Eur J Cancer 1996;32A:2004-2010.

46 Chin L, Liegeois N, DePinho RA, SchreiberAgus N: Functional interaction among members of the myc superfamily and potential relevance to cutaneous growth and development. J Invest Dermatol 1996;1:128-135.

47 Thompson EB: The many roles of c-myc in apoptosis. Annu Rev Physiol 1998;60:575600.

48 Plowman GD, Green JM, Culouscou JM, Carlton GW, Rothwell VM, Buckley S: Heregulin induces tyrosine phosphorylation of HER4/ p180erbB4. Nature 1993;366:473-475. 